\title{
PERUBAHAN SOSIAL MASYARAKAT PERMANDIAN WAE TUO DESA WAE TUO KECAMATAN KAJUARA KABUPATEN BONE
}

\author{
Harman $^{1}$, Andi Agustang ${ }^{2}$ \\ ${ }^{1,2}$ Program Studi Pendidikan Ilmu Pengetahuan Sosial Konsentrasi Pendidikan Sosiologi, Program \\ Pasca Sarjana Universitas Negeri Makassar \\ Harman1009ips13@gmail.com¹,andiagust63@gmail.com²
}

\begin{abstract}
ABSTRAK
Penelitian ini bertujuan untuk mengetahui 1) faktor-faktor yang mempengaruhi perubahan sosial masyarakat permandian Wae Tuo Desa Wae Tuo Kecamatan Kajuara Kabupaten Bone, 2) bentuk perubahan sosial masyarakat permandian Wae Tuo Desa Wae Tuo Kecamatan Kajuara Kabupaten Bone, dan 3) dampak perubahan sosial masyarakat permandian Wae Tuo Desa Wae Tuo Kecamatan Kajuara Kabupaten Bone. Jenis penelitian ini menggunakan penelitian kualitatif dengan penentuan informan dilakukan dengan teknik purposive sampling dengan kriteria adalah masyarakat lokal yang sudah tinggal 20-40 tahun di tempat tersebut, aparat desa dan masyarakat pengunjung yang paling jauh asalnya dan yang sering datang ke tempat tersebut. Teknik pengumpulan data yang digunakan yaitu teknik observasi, wawancara, dan dokumentasi. Hasil penelitian menunjukkan bahwa 1) Faktor-faktor yang mempengaruhi perubahan sosial permandian Wae Tuo Desa Wae Tuo Kecamatan Kajuara Kabupaten Bone terdiri dari dua faktor yaitu faktor Internal dan faktor Eksternal. Faktor internal meliputi: tingkat pendidikan dan kemajuan teknologi, pola pikir yang semakin terbuka dan toleransi dan konflik internal dalam masyarakat. Sedangkan dari faktor eksternal meliputi: tingkat interaksi masyarakat dan pengunjung, 2) Bentuk perubahan sosial masyarakat di permandian Wae Tuo Desa Wae Tuo Kecamatan Kajuara Kabupaten Bone yakni berdasarkan kecepatan terjadinya dan berdasarkan perencanaanya. Bentuk yang berdasarkan kecepatan terjadinya adalah perubahan evolusi sedangkan berdasarkan perencanaanya adalah perubahan yang dikehendaki, 3) Dampak Perubahan Sosial Masyarakat Permandian Wae Tuo Desa Wae Tuo Kecamatan Kajuara Kabupaten Bone terbagi atas dua yakni dampak positif dan dampak negatif. Dampak positifnya adalah masyarakat hidup lebih makmur, sedangkan dampak negatifnya adalah menghilangkan kebudayaan asli dan sikap individualistik
\end{abstract}

Kata kunci: Perubahan sosial, masyarakat, Permandian Wae Tuo.

\begin{abstract}
This study aims to find out the factors that influence social change in the community around the Wae Tuo baths Wae Tuo Village Kajuara District Bone Regency, to find out the form of social social change around the Wae Tuo baths Wae Tuo Village Kajuara District Bone Regency, and for the impact of changes social community around the Wae Tuo Baths Wae Tuo Village Kajuara District Bone Regency. This type of research uses qualitative research with the determination of informants carried out by purposive sampling technique with criteria are local people who have long lived in the place, community leaders, village officials and visitors. Data collection techniques used are observation, interviews, and documentation The results showed that 1) The factors that influence the social changes of Wae Tuo bathing in Wae Tuo Village, Kajuara District, Bone Regency consisted of two factors, namely Internal and External factors. Internal factors include: the level of education and technological progress, an increasingly open mindset and internal tolerance and conflict in society. While from external factors include: the level of interaction between the community and visitors, 2) The form of social change in the community in the bathing of Wae Tuo, Wae Tuo Village, Kajuara District, Bone Regency, based on the speed of occurrence and based on the plan. The form based on the speed of occurrence is evolutionary change while based on the plan is the desired change, 3) The Impact of Social Change in the Bathing Community of Wae Tuo Wae Tuo Village, Kajuara Subdistrict, Bone Regency is divided into two, namely positive and negative impacts. The positive impact is that society lives more prosperously, while the negative impact is eliminating indigenous culture and individualistic attitudes.
\end{abstract}

Keywords: Social change, society, Wae Tuo Baths. 


\section{PENDAHULUAN}

Indonesia merupakan Negara yang penduduknya terdiri dari berbagai macam suku, budaya dan adat istiadat yang berbeda-beda. Keberagaman tersebut dapat kita lihat dalam bentuk kepercayaan dan kebudayaan yang menjadi ciri khas dan kepribadian antara satu suku dengan suku yang lain, antara satu budaya dengan budaya yang lain. Perubahan dalam kehidupan suatu masyarakat merupakan sebuah keniscayaan yang tidak dapat dihindari manusia, hal ini karena inti dari jiwa masyarakat sendiri adalah dinamika, masyarakat senantiasa berubah di semua tingkat kompleksitas internalnya. Dinamika perubahan sosial yang terjadi dalam kehidupan masyarakat adakalanya merupakan perubahan yang besar dan memiliki pengaruh yang luas, dan adakalanya hanya merupakan perubahan yang kecil dengan pengaruh yang sangat terbatas (Soulisa, 2019), (Syukriyah, 2020).

Perubahan-perubahan dalam masyarakat dapat terjadi pada nilai-nilai sosial, norma-norma sosial, pola-pola perilaku organisasi, susunan lembaga kemasyarakatan, lapisan-lapisan dalam masyarakat, kekuasaan dan wewenang, interaksi sosial, dan lain sebagainya yang menjadi bagian dalam kehidupan masyarakat tersebut. Menurut Selo Soemardjan "perubahan sosial adalah segala perubahan perubahan pada lembaga-lembaga kemasyarakatan di dalam suatu masyarakat, yang mempengaruhi sistem sosialnya, termasuk di dalamnya nilai-nilai, sikap-sikap dan pola-pola prilaku di antara kelompokkelompok masyarakat" (Birsyada, 2018), (Diharjo, 2020). Apapun bentuk dan ragam perubahan yang terjadi dalam suatu masyarakat dapat dipastikan ada aktor sebagai agen perubahan tersebut, aktor itu adakalanya berupa individu dan kelompok (Hakim, 2020).

Fenomena perubahan sosial terjadi pula dalam kehidupan masyarakat Desa Wae Tuo Kecamatan Kajuara Kabupaten Bone. Secara historis masyarakat Desa Wae Tuo memiliki pola hidup dan adat istidat yang sedikit berbeda dengan masyarakat yang lain yang ada di Kabupaten Bone. Permandian Wae Tuo juga mempunyai fungsi sosial karena bagi masyarakat di luar Desa Wae Tuo permandian tersebut mempunyai daya tarik tersendiri sebagai objek wisata dan rekreasi. Tingginya intensitas pengunjung dari luar desa yang datang ketempat permandian Wae Tuo telah membawa pengaruh tersendiri terhadap kehidupan sosial masyarakat setempat, seperti dalam pola pikir masyarakat, perilaku masyarakat dan lain-lain sebagainya. Sistem mata pencaharian masyarakat di Desa Wae Tuo dulunya hanya bertani sekarang sudah mulai lebih kreatif dengan cara berjualan disekitar lokasi permandian Wae Tuo dalam rangka mencari penghasilan tambahan. Selain itu keseharian kehidupan masyarakat telah merespon perkembangan teknologi dan kesadaran akan pentingnya pendidikan, yang dulunya hanya sampai tingkat SD sekarang sudah banyak diantara mereka yang menyekolahkan anaknya sampai ke jenjang sarjana. Dari perkembangan itulah kemudian dunia lokal yang cenderung tradisional, berkembang jadi dunia global yang mengarah ke modern. Melihat segala kondisi dan konsekuensi tersebut, dunia lokal mengalami perubahan.

\section{METODE PENELITIAN}

Penelitian ini dilakukan dengan menggunakan pendekatan kualitatif kontruktivisme. Artinya, data dan fakta tentang perubahan sosial Desa Wae Tuo Kecamatan Kajuara Kabupaten Bone dihimpun melalui informasi-informasi lisan anggota masyarakat yang selanjutnya disebut sebagai informan. Metode dalam penelitian ini bertujuan untuk menggambarkan bagaimana peneliti akan mengumpulkan serta 
menganalisis data yang ada. Hal ini menempatkan posisi peneliti setara dan sebisa mungkin masuk dengan subjeknya, dan berusaha memahami dan mengonstruksikan sesuatu yang menjadi pemahaman si subjek yang akan diteliti.

Metodologi penelitian yang baik akan menghasilkan paradigma yang baru dalam pengembangan ilmu pengetahuan, dimana hasil pemikiran paradigma selalu tidak mencukupi dan terbuka untuk perubahan selanjutnya. Dengan kata lain hasil pemikiran melalui perubahan paradigma akan selalu bersifat relatif, hal ini bergantung pada data dan fakta yang diperoleh dari dunia nyata yang kemudian dianalisis menurut kaidah- kaidah ilmiah antara kelompok-kelompok masyarakat" (Agustang, 2011a)(Agustang, 2015).

Apapun bentuk dan ragam perubahan yang terjadi dalam suatu masyarakat dapat dipastikan ada aktor sebagai agen perubahan tersebut, aktor itu adakalanya berupa individu dan kelompok (Agustang, 2011b). Informan ditentukan secara purposive sampling yaitu dengan cara pemilihan berdasarkan ketentuan bahwa informan tersebut adalah yang melakukan, mengalami, mengetahui dan memahami persis masalah yang dikaji. Teknik digunakan apabila sampel dipilih secara khusus berdasarkan tujuan penelitian dengan persyaratan tertentu. Informannya adalah masyarakat lokal yang sudah lama tinggal di tempat tersebut dan masyarakat pengunjung dengan alasan dan kriteria sampel yang diperoleh benar-benar sesuai dengan penelitian yang akan digunakan. Teknik pengumpulan data dalam penelitian ini dilakukan melalui tiga cara observasi, wawancara, dan dokumentasi. Teknik analisis data yang digunakan peneliti melalui tiga tahapan kerja yaitu: reduksi data, penyajian data, dan penarikan kesimpulan (Huberman \& Miles, 2002)(Miles \& Huberman, 1994). Pengabsahan data yang digunakan yaitu triangulasi sumber.

\section{HASIL PENELITIAN DAN PEMBAHASAN}

\section{Faktor-faktor yang mempengaruhi perubahan sosial di sekitar permandian Wae Tuo Desa Wae Tuo Kecamatan Kajuara Kabupaten Bone}

Ada berbagai penyebab yang mengakibatkan masyarakat mengalami perubahan. Faktor penyebab itu dapat dikelompokkan menjadi dua, yaitu: faktor dari dalam masyarakat (internal) dan faktor yang berasal dari luar masyarakat (ekternal).

Faktor Internal, terdiri atas (Pertama) taraf pendidikan dan kemajuan teknologi. Berdasarkan wawanacara yang dilakukan oleh peneliti maka dapat dipahami bahwa para pengunjung yang datang memberi pengaruh bagi masyarakat setempat. Hal itu berkaitan dengan tingkat pendidikan mereka, masyarakat pun tentu berpikir bagaimana cara melanjutkan pendidikan anaknya. Jika dulu masyarakat acuh terhadap pendidikan, misalkan saja jika anaknya sudah tamat SD bisa langsung dinikahkan bagi yang perempuan dan bagi laki-laki mereka arahkan untuk langsung kerja agar dapat uang. Namun, hal itu sudah berubah sekarang masyarakat sudah berlomba-lomba menyekolahkan anaknya ke jenjang pendidikan yang tinggi. Perubahan sosial seperti ini tentu memberi dampak yang positif bagi masyarakat. Berdasarkan observasi yang dilakukan oleh peneliti di lapangan peneliti melihat beberapa orang yang datang dari berbagai kalangan dan pendidikan, mulai dari siswa SD hingga sampai guru pun berdatangan kesana untuk berekreasi. Pendidikan ialah usaha yang sengaja diadakan, baik langsung maupun tidak langsung, untuk membantu anak untuk mencapai kedewasaan (Parinussa, 2019), (Darmawan \& Arini, 2020).

Kedua pola pikir yang semakin terbuka dan toleransi, Berdasarkan wawancara dan observasi yang dilakukan oleh peneliti pada tempat tersebut maka dapat dipahami bahwa 
masyarakat di sekitar permandian sudah memiliki pola pikir yang terbuka untuk menerima para pengunjung yang datang ke kampong mereka, bahkan terkadang meraka menagajak para pengunjung untuk berislahturahmi ke rumah mereka. Kenyataan tersebut memberi bukti bahwa masyarakat setempat memiliki sikap toleransi terhadap pengujung. Ketika pengunjung ditanya pendapat mereka tentang masyarakat setempat, mereka menjawab bahwa memang masyarakat setempat ini memiliki sikap yang ramah. Sifat dan karakter masyarakat yang datang buka menjadi masalah bagi masyarakat untuk bersikap ramah dan sopan santun. Dari hasil observasi peneliti ketika berada di lokasi ditemukan bahwa masyarakat memang terbuka dengan pengunjung, itu dapat dilihat dari keramahan masyarakat ke pengunjung dan begitupun sebaliknya. Hal tersebut sesusai dengan yang dikemukakan oleh Jacobus Ranjabar bahwa Faktor pendorong terjadinya perubahan sosial yaitu dari pola pikir yang semakin terbuka dan toleransi. Sistem terbuka memungkinkan adanya gerakan sosial vertikal yang luas, atau berarti memberi peluang kepada individu untuk maju atas dasar kemampuan sendiri (Ranjabar, 2015). Agustang menyebutkan bahwa Seandainya dalam diri manusia tertanam kemauan yang keras untuk mencapai suatu keinginan, maka jalan kesuksesan sudah membentang untuk diraihnya. Namun sebaliknya jika tidak ada dorongan untuk maju dan selalu bersikap fatalistik, maka yang bersangkutan sedang berjalan menuju ke arah kemunduran (Agustang, 2017). Konsekwensinya selalu berada pada kondisi terbelakang dan tidak maju-maju. Untuk itu guna menyongsong hari esok yang lebih baik, maka mutlak ditumbuhkan semangat dinamis dengan motivasi yang kuat untuk maju.

Ketiga Pertentangan atau konflik internal dalam masyarakat, Berdasarkan wawancara dan observasi yang dilakukan oleh peneliti dapat diketahui bahwa konflik di sekitar permandian Wae Tuo juga pernah terjadi. Konfilk itu berupa masyarakat setempat dengan masyarakat setempat, biasa juga antar pengunjung yang datang yang akhirnya ketemu dipermandian dan ingin menyelesaikan masalahnya di permandian tersebut. Hal diatas sesuai dengan teori yang dikemukakan oleh Jacobus Ranjabar menyebutkan bahwa faktor risiko terjadinya perubahan sosial meliputi Timbulnya Masalah Sosial (Ranjabar, 2015). Masalah sosial merupakan risiko perubahan. Suatu masyarakat yang sedang mengalami proses perubahan pasti menimbulkan masalah sosial. Hal itu terjadi karena kondisi dalam masyarakat itu sendiri, atau dari luar yang mengalami perubahan sehingga tidak dapat lagi diterima oleh masyarakat tersebut seperti pertumbuhan penduduk dan kerusakan lingkugan hidup.

Faktor Ekternal, terdiri atas: Pertama. Tingkat interaksi Masyarakat dengan Pengunjung, Berdasarkan wawancara yang dilakukan oleh peneliti maka dipahami bahwa dengan interaksi masyarakat setempat dengan pengunjung yang dapang dapat menjadi faktor eksternal atau faktor yang berasal dari luar masyarakat menjadi faktor perubahan sosial masyarakat setempat. Dari hasil observasi yang dilakukan oleh peneliti di permandian Wae Tuo dapat dipahami bahwa memang masyarakat setempat senang dengan datangnya para pengunjung ke permandian Wae Tuo. Seringnya masyarakat setempat berinteraksi dengan pengunjung menjadi faktor penyebab perubahan sosial. Berdasarakan teori dari George Simmel dalam sudut pandangnya memusatkan perhatiannya pada dunia nyata yang terdiri dari peristiwa-peristiwa, tindakan-tindakan, interaksi-interaksi, dan seterusnya yang tidak terhitung banyaknya. Artinya dengan seringnya masyarakat berinterksi dengan pengunjung maka terjadi perubahan sosial.

Kedua. Lingkungan (Keadaan Alam), Berdasarkan hasil penelitian dan observasi lapangan, dapat diketahui bahwa di di Desa Wae Tuo juga pernah mengalami kekeringan, hal itu di sampaikan oleh beberapa informan bahwa dulu pernah terjadi kekeringan yang 
melanda Desa tersebut disebabkan karena sumber air yang ada ditutup, akhirnya membuat masyarakat resah dengan kondisi tersebut. Namun, ada seorang yang mampu kembali menemukan sumber mata air yang sangat melimpah, dan itu berada di Dusun Wae Tuo yang kemudian dimanfaatkan oleh masyarakat setempat maupun luar untuk kebutuhannya. Hal tersebut sesui dengan teori yang dikemukakan oleh Soerjono Soekanto faktor penyebab perubahan sosial yang berasal dari luar masyarakat yaitu dari lingkungan Terjadinya banjir, gunung meletus, gempa bumi, dll yang mengakibatkan penduduk di wilayah tersebut harus pindah ke wilayah lain (Soekanto \& Sulistyowati, 2013).

Ketiga. Kontak dengan Kebudayaan Lain, Berdasarkan penelitian dan observasi yang dilakukan oleh peneliti, maka dapat pula di pahami bahwa dalam masyarakat yang disekitar permandian Wae Tuo mengalami perubahan disebabkan karena kontak dengan kebudayaan lain. Hal ini utamanya terjadi pada kalangan remaja milenial yang tidak sedari awal ditanamkan tenatang nilai-nilai kebudayaannya menyebabkan para remaja mengikut dengan kebudayaan yang lain. Dari pemaparan diatas, maka sesuai dengan teori yang dikemukakan oleh Soerjono Soekanto bahwa Masuknya kebudayaan Barat dalam kehidupan masyarakat di Indonesia menyebabkan terjadinya perubahan (Soekanto \& Sulistyowati, 2013).

\section{Bentuk Perubahan Sosial Masyarakat di Sekitar Permandian Wae Tuo Desa Wae Tuo Kecamatan Kajuara Kabupaten Bone}

Berdasarkan Kecepatan terjadinya terdiri atas: Pertama Perubahan Evolusi, Dari hasil wawancara dan observasi yang dilakukan oleh peneliti maka dapat diketahui bentuk perubahan sosial yang terjadi adalah dengan secara lambat. Hal itu dapat dilihat dari pola sikap masyarakat yang terbuka dengan para pengunjung yang datang, jika dulu masyarakat tidak terbuka dengan pengunjung yang datang namun sekarang sudah terbuka bahkan terkadang masyarakat mengajak para pengunjung untuk singgah di rumahnya. Hal ini juga di dukung oleh peran pemerintah yang memberikan pelatihan kepada masyarakat setempat bagaimana sikap menghormati tamu yang datang ke tempat mereka. Pemaparan tersebut sesuai dengan teori yang dikemukan oleh Baharuddin memberi penjelasan bahwa. Perubahan evolusi adalah perubahan sosial yang berlangsung secara lambat dan dalam waktu yang cukup lama dengan tidak adanya kehendak tertentu dari masyarakat yang bersangkutan. Perubahan ini biasanya terjadi karena perkembangan kondisi masyarakat dalam menjalankan usaha-usaha untuk memenuhi kebutuhan hidupnya (Cahyono, 2016).

Berdasarkan Perencanaanya: Perubahan Sosial yang Direncanakan, Berdasarkan hasil wawancara dan penelusuran peneliti maka dapat di ketahui bahwa perubahan sosial yang direncakan di permandian Wae Tuo itu berada pada sektor sosial ekonomi masyarakat. Hal itu dapat dilihat dari kegiatan masyarkat disekitar permandian Wae Tuo yang banyak berjualan hasil pertanian mereka. Adapula yang memanfaatkan air Wae Tuo untuk mengairi sawahnya untuk menanam berbagai macam sayuran dan buah-buahan. Selain itu, ada juga masyarakat yang bekerja di perusahaan air minum Lestari yang airnya berasal dari permandian wae Tuo. Pemaparan tersebut sesuai dengan teori yang dikemukan oleh Baharuddin bahwa Perubahan yang direncanakan adalah perubahan yang terjadi karena adanya perkiraan atau perencanaan oleh pihakpihak yang menghendaki perubahan tersebut (agen of change) (NURROHIMAH, n.d.). Misalnya pemerintah setempat memang mengingkan perubahan tersebut karena berdampak pada perekonomian masyarakat 


\section{Dampak Perubahan Sosial Masyarakat di Sekitar Permandian Wae Tuo Desa Wae Tuo Kecamatan Kajuara Kabupaten Bone}

Dampak Positif, Masyarakat Hidup Lebih Makmur. Hal itu berdasarkan wawancara dan observasi yang dilakukan oleh peneliti bahwa dengan permandian Wae Tuo ini masyarakat lebih kreatif memanfaatkan segala potensi seperti halnya dengan berjualan di sekitar permandian untuk memenuhi kebutuhan pengunjung, adapula yang menjual hasil pertanian seperti sayur-sayuran yang segar yang mampu memikat hati pengunjung untuk membelinya. Dari pemaparan diatas didukung oleh teori Selvie Tumengkol bahwa Perubahan yang terjadi didalam kehidupan masyarakat tentu akan berdampak pada berubahnya pola kehidupan dan karakter masyarakat itu sendiri. Salah satu yang disebutkan adalah menjadikan masyarakat hidup lebih makmur (Tumengkol, 2012). Seperti yang dikemukakan oleh Agustang, A, dalam hal menanggulangi ketertinggalan dan krisis ekonomi antara lain menjaga stabilitas makro ekonomi, stabilitas harga, menciptakan lapangan kerja produktif, menjaga iklim investasi, menjaga regulasi perdagangan, meningkatkan produktivitas sektor pertanian, dan mengembangkan infrastruktur wilayah tertinggal (Agustang, 2007).

Dampak Negatif, antara lain: Pertama, Menghilangkan Kebudayaan Asli. Seperti wawancara yang dilakukan oleh peneliti dapat diketahui bahwa perubahan sosial ini memberi dampak negatif bagi masyarakat seperti yang terjadi pada kalangan pemuda. Akibat dari proses interaksi antara masyarakat dan pengunjung, maka para pemuda ini melihat sifat dan karakter pengunjung yang datang. Tradisi yang dulu di pegang oleh masyarakat kini mulai ditinggalkan seperti tradisi ma рапо тапи (menurunkan ayam ke kolam) di permandian dan mappatettong bola (mendirikan rumah kayu) kini sudah mulai ditinggalkan. Kedua, Sikap individualistik. Berdasarkan Wawancara yang dilakukan oleh peneliti, maka dapat di pahami bahwa di permandian Wae Tuo muncul sikap individualis pada sebagian kecil masyarakat. Sikap tersebut disebabkan karena jarangnya masyarakat bergaul dengan yang lainnya dan juga disebabkan dari pekerjaan masyarakat tersebut cukup padat maka tidak ada waktu untuk berkumpul dengan masyarakat lainnya. Di zaman yang sudah modern ini sangat banyak kemudahan yang didapatkan membuat masyarakat tidak terlalu membutuhkan orang lain. Berdasarkan teori dari Selvie Tumengkol bahwa dengan terjadinya persaingan hidup yang semakin ketat ataupun keras kedua hal ini mengakibatkan nilai-nilai kemanusiaan mengalami pergeseran nilai (Tumengkol, 2012).

\section{PENUTUP}

Berdasarkan hasil analisis penelitian yang telah dilakukan maka dapat ditarik beberapa kesimpulan sebagai berikut:

1. Faktor-faktor yang mempengaruhi perubahan sosial di sekitar permandian Wae Tuo terdiri dari dua faktor yaitu faktor Internal dan faktor Eksternal. Faktor internal meliputi: Taraf pendidikan dan kemajuan teknologi, Pertentangan atau konflik dalam masyarakat. Sedangkan dari faktor ekternal meliputi: tingkat interaksi masyarakat dengan pengunjung, Lingkungan dan kontak dengan kebudayaan lain.

2. Bentuk perubahan sosial masyarakat di sekitar permandian Wae Tuo terbagi atas dua bentuk yakni berdasarkan kecepatan terjadinya dan berdasarkan perencanaanya. Bentuk yang berdasarkan kecepatan terjadinya adalah perubahan evolusi dan sedangkan berdasarkan perencanaanya adalah perubahan yang dikehendaki. 
3. Dampak Perubahan Sosial Masyarakat di Sekitar Permandian Wae Tuo terbagi atas dua yakni dampak positif dan dampak negatif. Dampak positifnya adalah masyarakat hidup lebih makmur sedangkan dampak negatifnya adalah menghilangkan kebudayaan asli dan sikap individualistik.

\section{DAFTAR PUSTAKA}

Agustang, A. (2007). Entaskan Kemiskinan: Analisis Kinerja Pembangunan Indonesia. Makassar: Indobis Publisher.

Agustang, A. (2011a). Filosofi Research (Dalam Upaya Pengembangan Ilmu). Makassar.

Agustang, A. (2011b). Pendekatan Penelitian Kualitatif dan Kuantitatif Suatu Tinjauan Kritis. Makassar: Andira Publisher.

Agustang, A. (2015). Dasar-Dasar Filsafat Penelitian Untuk Pengembangan Ilmu. CV Multi Global, Jalan Maccini Sawah.

Agustang, A. (2017). Sufisme dan Kemiskinan Kultural pada Komunitas Nelayan di Pesisir Teluk Bone Kecamatan Sibulue.

Birsyada, M. I. (2018). Social Change in Yogyakarta: Past And Now A Selo Soemardjan. Jurnal Historia Universitas Muhammadiyah Metro, 6.

Cahyono, A. S. (2016). Pengaruh media sosial terhadap perubahan sosial masyarakat di Indonesia. Jurnal Publiciana, 9(1), 140-157.

Darmawan, K. E., \& Arini, N. W. (2020). Peran Guru Profesional Untuk Peningkatan Mutu Pendidikan Agama Hindu Melalui Efektivitas Dan Kreativitas Pola Interaksi Di Sekolah. Sang Acharya: Jurnal Profesi Guru, 1(2), 1-18.

Diharjo, S. M. (2020). Dinamika perubahan sosial dalam teori konflik. Jurnal Ilmu Komunikasi Dan Bisnis, 5(1), 1-17.

Hakim, L. (2020). Filsafat Ilmu Dan Logika: Dialektika Perubahan. Penerbit Lakeisha.

Huberman, M., \& Miles, M. B. (2002). The qualitative researcher's companion. Sage.

Miles, M. B., \& Huberman, A. M. (1994). Qualitative data analysis: An expanded sourcebook. sage.

NURROHIMAH, I. (n.d.). Perubahan Sosial Petani Kopi Tumpangsari Lada di Desa Pace Kecamatan Silo Kabupaten Jember.

Parinussa, L. (2019). The Effect Of The Application Examples Non Examples Learning Model In Science Biology Subjects To Improve The Control Of The Concept Of 7th Grade Students In SMPN 9 Ambon. Global Science Education Journal, 1(2), 136146.

Ranjabar, J. (2015). Perubahan Sosial: Teori-Teori dan Proses Perubahan Sosial serta Teori Pembangunan. Bandung: Alfabeta.

Soekanto, S., \& Sulistyowati, B. (2013). Sosiologi Suatu Pengantar (Edisi Revisi). Jakarta: Raja Grafindo Persada.

Soulisa, M. S. (2019). Perubahan Sosial Masyarakat Negeri Hena Lima Pasca Bencana Banjir Wae Ela Di Kecamatan Leihitu Kabupaten Maluku Tengah. Dialektika, 12(1), 57-70.

Syukriyah, A. (2020). Perubahan sosial pasca adanya wisata alam gosari (Wagos) di desa Gosari kecamatan Ujungpangkah kabupaten Gresik. UIN Sunan Ampel Surabaya.

Tumengkol, S. M. (2012). Teori Sosiologi Perspektif tentang Teori Konflik dalam Masyarakat Industri. Karya Ilmiah Universitas Sam Ratulangi, Fakultas Ilmu Sosial Dan Ilmu Politik, MANADO. 